\title{
A study on risk assessment and its management in India
}

\author{
Kinnaresh Patel \\ M.E '15 Construction Engineering Management, Texas A\&M University, College Station
}

Email address:

kinnaresh_99@yahoo.com

\section{To cite this article:}

Kinnaresh Patel. A Study on Risk Assessment and its Management in India. American Journal of Civil Engineering.

Vol. 1, No. 2, 2013, pp. 64-67. doi: 10.11648/j.ajce.20130102.13

\begin{abstract}
All of themost challenging construction projects worldwide involve a variety of complex processes working simultaneously. Managing these processes can be quite a challenge for the management. A big part of meeting these challenges is mitigating the RISKS involved. Risk management includes identifying risks, assessing risks either quantitatively or qualitatively, choosing the appropriate method for handling risks, and then monitoring and documenting risks. This study identifies the procedures for risk identification, management and its perception from the Indian construction industry players. Time and cost management need to be fully integrated with the identification process. Time constraints and project managers with sufficient experience are critical when identifying the level of risk for large and/or complex projects. The aim of this study is to advocate for a method of risk mitigation which includes a well-documented procedure which serves as a one stop-solution to all the risks that would emanate in the future.
\end{abstract}

Keywords: Risk Assessment, Risk Management, Risk Identification, Construction Projects, India

\section{Introduction}

Risks can be defined as an event that negatively affects the project objectives, which are:

1) Time and Schedule

2) Cost

3) Quality of work

A risk is nothing but a situation. Risks are neglected by construction contractors and consultants while considering bids and tenders. Project risk management is widely recognised as one of the most critical procedures and capability areas in the field of project management. Risks are critical to a project as every critical activity is associated with a risk.

Also, the number of risks arising from a task is directly proportional to the number of people working on it. Mismanagement is one of the various sources of risk. Risk mitigation depends a lot on the co-ordination of work between different people on the project. So naturally, less the number of people working on a project, less is the chance of the risk taking place.

Nowadays, almost all of the big scale projects are sublet to sub-contractors, and therefore risk assessment and mitigation has become more and more difficult. As a developing country, India has not focused on risk management. This study aims to better understand the risk identification process and other risk processes.It has already been recognised that a clear understanding of the risks born by each participant leads to better risk allocation. The objective of this study is to find means of identifying risk management and other processes that can be utilised and to make new suggestions on the use of these risk management methods.

\section{How is Risk Assessment approached in the Construction Industry in India}

This study was performed with respect to the surveys and observation of management techniques used in today's construction industry in India. Every project has big important events or milestones with respect to cost and time which are pre-marked by the management at the start of the project. They are tracked regularly. Project managers use these milestones as pointers to risk mitigation. They look out for any negative cost impact or delays in activities of these milestones. Now in most of the cases, these milestones are not met. The main reason for that is the approach of the project manager towards the pertinent risks. Their approach is of the wait and watch type. They react only after they find themselves in a fix, as opposed to being proactive and taking necessary steps to prevent the risk from taking place. There is a need of a whole system to be in place, so before any activity takes place, all possible 
risks are identified and acted upon.

\section{Risk Identification and approach to Risk Management}

Risk identification is an iterative process that involves the project team, stakeholders and other managers affected by or who affect the project, and finally outside individuals who can comment on the completeness of the risk identification based on their similar experiences.

The challenge lies in identifying beforehand all the risks that you might face so that the project team is well equipped and ready to mitigate it systematically. While it is a well-known fact that risk identification is a step by step process, i.e. new risks might appear only when the project reaches a certain level, this is exactly where analysis of historical data comes into play. The project team has to collect all possible relevant data of previous projects and take into account all the similar risks that can be linked even remotely. This can be done with the help of industrial checklists.

By identifying risks at an early stage of planning a construction project or a tender and assessing their relative importance, the project management can be adapted to reduce the risks and allocate them to the parties best able to control them or absorb them should they occur. Studies should be carried out early in the life of a project, well before decisions are made to proceed with the project.Risk Management can be divided into two main ways: 1) Informal approach \&2) Formal approach

\subsection{Informal Approach}

In this approach, risks are mitigated as and when they come. They are not predetermined.

The key aspect here is that no preparation is done on collecting any data for risk identification.

One of the most widely used techniques in the informal approach to risk management is the provision of contingency funds. There are two main types of contingency funds: lump sum contingencies and percentage contingencies.

Here, the project depends a lot on the on-site and the sub-contractor teams. Another disadvantage is that discussions and brainstorming at all stages becomes a necessity.

Table 1.Pros and Cons of the Informal approach towards risk assessment

\begin{tabular}{|c|c|c|}
\hline \multicolumn{2}{|l|}{ PROS } & CONS \\
\hline (a) & Economical in some cases & $\begin{array}{l}\text { (a) You need an } \\
\text { experienced and loyal } \\
\text { execution team }\end{array}$ \\
\hline (b) & $\begin{array}{l}\text { You don't hire special } \\
\text { teams to collect any data or } \\
\text { identify risks }\end{array}$ & $\begin{array}{l}\text { (b)Discussions at all stages } \\
\text { might be verytime consuming }\end{array}$ \\
\hline \multicolumn{2}{|c|}{$\begin{array}{l}\text { (C)Could be useful in a project } \\
\text { involvingnew or unusual risks. }\end{array}$} & $\begin{array}{l}\text { (C) Correct selection of } \\
\text { people for brainstorming must } \\
\text { be done } \\
\text { (d)Lack of objectivity. }\end{array}$ \\
\hline
\end{tabular}

\subsection{Formal Approach}

Here at the start of the project the project management sits down and chalks out allthe possible risks that are most likely to come up during the course of the project.

All the risks likely to come up in the worst case scenario are predicted, and proper solutions are discussed regarding that.

In this method it is viable for a company to have a set of industrial data that has been gathered by experience over the years in the form of checklists.

\begin{tabular}{ll}
\hline PROS & CONS \\
\hline (a) Objectivity. & (a)It may be costly. \\
(b) It saves a lot of time as the & (b) It takes up a lot of \\
management is prepared to & resources at the start of the \\
mitigate the risks. & project. \\
(c) Chances of failure are low. &
\end{tabular}

\section{Important Tools/Aspects in Risk Identification and Assessment}

\subsection{Work Breakdown Structure}

Before the commencement of the project all tasks are listed, broken down into manageablesubtasks\& the schedule is prepared via MS Project or Primavera. It breaks down activities into smaller and more specific sub-tasks which gives an exact idea of what needs to be done and the amount of resources to be spent on that task.It can have as many levels as possible.A WBS with the schedule is imperative in the risk identification particularly in an industrial project involving structural steel.The WBS in the schedule can be used to generate a BIM or VDC (Virtual Design Construction)video which would give a clear idea of the activities to be performed in a chronological order.

\subsection{Product Specifications}

Product Specifications is a literature given to the contractors by the owners which gives a detailed description on how the product is to be executed.There are additional or new (other than the common ones) risks for products which have particularly different specification.

\subsection{Risk Matrix}

A project manager with the help of a specialist should create a matrix that lists out all those risks which may have a considerable cost \& time impact.

\subsection{Resource Plan}

In this paper resources refer to men, materials \& machinery. Resources arethe Achilles heel of all the construction processes.In India there are more risks arising out of the lack of or mismanagement of resources rather than the activities themselves.Hence while brainstorming it 
is very important to assign the activities just the right amount of resources required.

\section{Methodology}

To achieve the objectives of this research, questionnaires were deemed to be the most effective tool for gathering information. These questions helped identify any projects that should definitely not be undertaken by the parties and those which, although risky, should be examined further after a more rigorous examination of the potential sources of risk. This study was carried out based on a literature review and a questionnaire survey. The data were collected through questionnaires, which were distributed through postal and electronic mailing to selected groups of 32 respondents (mainly people who work for construction companies/ firms who enjoy a leading role in planning and construction management, e.g., project managers, general managers, civil engineers, site managers, site engineers, supervisors) from government, construction and consulting companies and firms in the defined area of study.

\section{Analysis and Discussion}

Three Non-Parametric Tests were conducted with the help of questionnaires \& their results were as follows:

\subsection{The Most Preferred Method of Risk Identification by the Indian Construction Players}

Table 2.Result ofthequestionnaire survey

\begin{tabular}{lll}
\hline $\begin{array}{l}\text { Methods Used For Risk } \\
\text { Identification }\end{array}$ & Mean & Rank \\
\hline Brain-storming sessions & 3.56 & 1 \\
$\begin{array}{l}\text { Analysis of historical } \\
\text { data for similar projects }\end{array}$ & 1.09 & 2 \\
$\begin{array}{l}\text { Use of industrial check- } \\
\text { lists }\end{array}$ & 1.35 & 3 \\
\hline
\end{tabular}

The results show that brain-storming sessions were the most significant method that contributed to identifying the risks of a project. Brain-storming sessions and analysis of historical data for similar projects were found to be the most preferred methods of risk identification in the Iranian construction industry. However, it was suggested by the respondents that these practices led to informal risk identification.

\subsection{The Relative Importance of Risk Identification Processes}

These results are shown based on their mean value (the average indexes).

The mean for some processes indicates that time management and cost management have affected the process of identifying the risk.
Table 3. Result ofthe questionnaire survey

\begin{tabular}{|c|c|c|}
\hline Risk Identification Process & Mean Rank & Rank \\
\hline $\begin{array}{l}\text { Is the risk identification process fully } \\
\text { integrated with cost management and time } \\
\text { management processes and the project } \\
\text { office? }\end{array}$ & 4.3812 & 1 \\
\hline $\begin{array}{l}\text { Does documentation exist on all processes } \\
\text { and standards for identifying risk events? }\end{array}$ & 3.9393 & 2 \\
\hline $\begin{array}{l}\text { Does the process include proper tools for } \\
\text { teams to identify risks (checklists, } \\
\text { automated forms, etc.)? }\end{array}$ & 3.8323 & 3 \\
\hline $\begin{array}{l}\text { Does the organization have a documented } \\
\text { repeatable process for identifying project } \\
\text { risks which is fully implemented? }\end{array}$ & 2.1020 & 4 \\
\hline $\begin{array}{l}\text { Are all processes in place, documented and } \\
\text { being used? }\end{array}$ & 2.0353 & 5 \\
\hline
\end{tabular}

Rating Scale: (Agreement)

$1=$ Strongly disagree; $2=$ Disagree; $3=$ Less agree; $4=$ Agree; 5 = Strongly agree

The main objective of this section is to assess the level of knowledge and awareness, including the perception of construction industry players, of identifying the level of project risk in general. Questions were ranked based on the level of importance (the average indexes) to identify the specifications of project risk.

\subsection{Maximum Types of Risks Emanating from One Source}

Table 4.Result of the questionnaire survey

\begin{tabular}{llc}
\hline Sources Of Risks & Mean Rank & Rank \\
\hline Financial & 7.56 & 1 \\
Quality & 7.01 & 2 \\
Geographical & 6.01 & 3 \\
Environmental & 5.39 & 4 \\
Legal & 4.28 & 5 \\
Social & 3.23 & 6 \\
\hline
\end{tabular}

Rating Scale: (Agreement)

$1=$ Strongly disagree; $2=$ Disagree; $3=$ Less agree; $4=$ Agree; 5 = Strongly agree

During a construction project, risks can result from many circumstances. Based on the data analysed earlier, a total of six sources of risk in construction projects were compared, as shown in table. Financial, construction and demand of quality and product risks are the greatest risks in construction projects. There are some sources of risk associated with engineering projects that have been identified. These sources of risks, the risk drivers, could be used as a checklist. However, the key sources of project risks are essentially the same. 


\section{Conclusion}

The research results were obtained through questionnaire surveys conducted in India. The ways to identify project risk that have been particularised for construction projects have been presented from diverse points of view (from government, consultants and contractors) and construction companies and firms that may be helping the process of dealing with the project in the planning and construction phases. From the results it is safe to say that majority of the construction projects have no systematic procedures in place to deal with the risks. Risk management is done in a very informal manner.

The brain-storming sessions were found to be the most preferred method of risk identification in the Indian construction industry. The risks associated with Indian construction projects included financial risks (project funding problem), construction risks and demand/ product risks. These risks commonly prevent the completion of construction project objectives in India. In contrast with other countries, Indian construction projects generally have been practiced with an informal approach for risk management. In most situations, government employees, consultants and contractors wait until issues arise during construction phases, and when they do the discussions are informal and intermittent.

Hence there is a thriving need to have a welldocumented procedure which should be a one stop solution to all the risks that are likely to be faced. It might be difficult to get all the data, information \& knowledge together in order to identify the risks beforehand. But that is where the prospect of research stands in value. There should be a more wholesome approach towards risk management instead of the present sporadic approach of meeting the risks as and when they come.

\section{References}

[1] Al-Bahar, J.F. and Crandall, K.C. (1990). Systematic risk management approach for construction project. Journal of Construction Engineering and Management, 116(3): 533546.

[2] Artto, K.A. (1999). Development of World-Class Practices in Project Companies. In The Future of Project Management, Project Management Institute Research Series. Newtown Square, PA: Project Management Institute (PMI), 127-137.

[3] Kendrick, T. (2009). Identifying and Managing Project Risk: Essential Tools for Failure-Proofing Your Project. 2nd Edition. New York: AMACOM Div. American Management Association.

[4] Project Management Institute. (2004). A Guide to the Project Management Body of Knowledge. Newtown Square, Pennsylvania: PMI.

[5] Thompson, P. and Perry, J.G. (1992). Engineering Construction Risks: A Guide to Project Risk Analysis and Assessment Implications for Project Clients and Project Managers. London: Thomas Telford.

[6] Wysocki, R.K. (2004). Project Management Process Improvement. Norwood: Artech House. 